\title{
DISTRIBUTED LAG EFFECTS OF TRANSPORTATION EXPENDITURES ON RURAL INCOME AND EMPLOYMENT
}

\author{
Laurence M. Crane and David J. Leatham*
}

\begin{abstract}
Effects of transportation expenditures on income and employment were evaluated using polynomial distributed lags. Results indicate that a 1 percent increase in transportation expenditures increased farm income in rural areas by 1.94 percent, distributed over four years, and nonfarm income by 0.86 percent, distributed over six years. Similar positive results were found for farm and nonfarm employment in rural areas distributed over nine years.
\end{abstract}

\section{INTRODUCTION}

Transportation investment has long been an important factor contributing to a state's economic infrastructure base. State expenditures for construction, maintenance, and rehabilitation of a transportation network create intertemporal benefits. The relationships between these benefits and transportation expenditures, and how they affect the economic vitality of the rural and urban areas within a state, need to be examined.

Expenditures for public highways support the third largest function of state and local governments. Expenditures for education and welfare are first and second. Policymakers are faced with difficult choices in providing adequate transportation facilities, funding education and other competing state programs, and increasing economic activity, all within the bounds of a limited budget and limited resources. As some sectors within the state economy grow and others decline, policymakers are faced with the task of being able to target programs that are not only geographically specific, but industry specific as well.

A state's ability to maintain its existing network of roads in good condition and to increase capacity in time to prevent bottlenecks is important to all highway users, and it ensures strong economic growth. One recent study shows that merely halting deterioration in the nation's highway network would improve economic growth for the economy as a whole, with national income 3.2 percent higher by 1995, employment 2.2 percent higher, and inflation 8 percent lower than if road

\footnotetext{
*Assistant Professor of Agricultural Economics, North Dakota State University, and former Research Associate, Texas Transportation Institute; Associate Professor of Agricultural Economics, Texas A\&M University, respectively. Technical Article No. 25626 of the Texas Agricultural Experiment Station.
} 
conditions were allowed to continue to deteriorate as in the late 1970s (TRIP 1987). This is important to Texas, which has more than 72,000 miles of highways, including 3,200 miles of interstate highways, more than 27,000 miles of primary (U.S. or state-numbered) roads, about 41,000 miles of secondary (farm-to-market) roads, and about 20,000 bridges (Anderson, Murray, and Farley 1984).

The purpose of this study is to investigate the intertemporal effect that expenditures on transportation infrastructure in Texas have on the state's economy. Specifically, the effect of state transportation expenditures (construction and maintenance) on the income and employment levels in the rural and urban areas of the state are modeled. An understanding of these relationships could aid policymakers in the allocation of public funds and in the formation and timing of policy instruments to aid the economic revitalization of distressed areas.

\section{PREVIOUS RESEARCH}

Several studies have shown significant linkages between economic development and transportation expenditures (Stephanedes and Eagle 1986; U.S. Congress 1978; Wilson, Stevens, and Holyoke 1982; Sullivan 1988). Understanding the timing and strengths of these linkages, and the differences in impact between urban and rural areas, is important. Rural areas are disproportionately dependent on the agriculture and manufacturing sectors. Developing rural physical infrastructure is an essential dimension of rural development policy (Knutson and Fisher 1989).

As the various economic sectors of the country, including the economic and geographic regions in the state of Texas, rebound from the severe recession in the agriculture and mining sectors, various agencies and political bodies have become more vocal in advocating a move toward so-called economic diversification (John, Batie, and Norris 1988). In general, investments in infrastructure, such as transportation, are necessary but not sufficient conditions for sustained economic development. For this reason, understanding and documenting the effects transportation expenditures have on a specific area are increasingly important to governmental and administrative bodies, as are all public expenditure programs (Sullivan 1988). As a means of promoting and sustaining economic activity, state governments are increasing their levels of support for various growth strategies and promotions (Cherwony and Cartwright 1985). There has been practically no statistical analysis of the effects of these policies. In the future, agencies are also going to need to justify their budgets in an economic development and diversification context more so than they have been required to do in the past (Center for Applied Research 1987). 
In an attempt to revitalize rural economies, several states have passed legislation creating enterprise development areas or zones (Roggenburk and Rasin 1985). The enterprise zone concept is founded on the belief that the formation of new business activity that will create employment opportunities in these rural zones can be fostered through incentives and innovative projects. However, very little is known about the factors that influence where new business location will occur and how much employment will be generated. Location theory has been used in various studies to examine the relationship between transportation costs and level of service and regional economic development. In one study, this was done to determine whether public transportation infrastructure and freight subsidies can be expected to stimulate industrial development in a region (Wilson, Stevens, and Holyoke 1982).

Population migration and growth are affected by the state's economic employment climate. For employment, differences in county growth are most often determined by economic and demographic conditions (Carlino and Mills 1987). Carlton simultaneously modeled both the location and employment choice of new branch plants (Carlton 1983) and found that energy costs and existing concentrations of employment have a surprisingly large effect on plant location decisions, whereas taxes and state incentive programs do not seem to have major effects. For highly sophisticated industries of the type often located in urban areas, the available technical expertise, specialized resources such as labor skills and education, and factors that help attract and maintain a skilled labor force, such as state and local taxes, are important. Less technical industries-the type often found in rural areas-are influenced more by the traditional location factors of market access and transportation (Herzog, Schlottmann, and Johnson 1986). The Federal Highway Administration has issued administrative criteria for the selection of economic growth areas as they relate to transportation facilities and needs (Siccardi 1986). As the highway network becomes saturated, it exhibits less of a developmental effect and begins to act as an agent to increase personal mobility (Wilson, Graham, and Aboul-Ela 1985).

Economic activity is also increasingly being used by state departments of transportation as a criterion and justification for highway funding decisions (Altshuler 1977). Past studies of the interactions between highway expenditures and economic development have provided little evidence supporting this funding justification criterion (Wilson, Stevens, and Holyoke 1982; Briggs 1983). However, recent econometric studies have found that highway expenditures lead to temporary increases in employment during the construction stage (Eagle and Stephanedes 1987; Stephanedes and Eagle 1986, 1987), and strong evidence exists of long-term economic development above the trend in the large regional centers of Minnesota (Stephanedes 1989). Also, a recent Texas study found 
transportation expenditures to have a positive lagged impact on total employment (Crane, Burke, and Hanks 1991).

Dye (1980) examined the differences in taxing and spending among the American states and their impact on economic growth and development. His findings show little association between taxing policies and economic growth. However, a state's spending policies were strongly correlated to its economic development. The strongest relationship was between highway spending and economic development. Spending in the late 1960s correlated with economic development in the early and mid-1970s. He concludes that the data suggest investment in all areas of a state's infrastructure-highways, energy, water, mass transit, etc.-promotes economic development. Tax incentives did not have a significant impact in the development of a state's economy.

It has also been found that the impact that highways, and highway spending, have on economic development plays a significant role in highway planning (Forkenbrock and Plazak 1986). Economic development is becoming a major goal of highway planning in most states, and many states have created programs designed to find the economic impact of highway development. For example, Iowa's RISE program (Revitalize Iowa's Sound Economy), administered by the Iowa DOT, investigates the impact that highway construction and maintenance expenditures will have on economic development.

In the current time of fiscal austerity, taxpayers are demanding the most effective publicly financed programs, including highway construction and maintenance expenditures. The determinants of general economic growth have been modeled in a whole menu of theories (Hoselitz, Spengler, Letiche, McKinley, Buttrick, and Bruton 1960; Jhingan 1975). The project and/or regionally specific models are of more practical use to highway department personnel (Politano and Roadifer 1989) and to other policymakers who act to strengthen distressed areas. There is a need, however, for further research at the project, regional, and state levels in all areas of transportation management, administration, and policy planning (Weiner and Graeub 1986). This research should evaluate the impact of expenditures on different economic, demographic, and geographical regions. The timing and magnitudes of the lagged effects are an important part of this evaluation. 


\section{METHODOLOGY}

\section{Distributed Lag Model}

In a comprehensive Minnesota study, Vector Autoregressions (VAR), structural plots, and Granger-Sims causality tests were used in a sector analysis to evaluate highway expenditures and county employment (Stephanedes 1989). The length of the lags in these models was restricted due to the number of coefficients being estimated. A less restrictive approach to determine the length and magnitude of highway expenditures on employment and income is a distributed lag model.

Distributed lags arise in theory when any economic cause produces its effect after some lag in time, so that this effect is not felt all at once but is distributed over a period of time. For example, the full effects of expenditures on transportation are not felt immediately, but are felt gradually, and the full effect is realized only after a considerable period of time has elapsed. Determining the length and magnitude of this lagged impact is essential to the understanding of how expenditures on transportation affect the economy. A general distributed lag model can be stated as:

$$
Y_{t}=\sum_{j=0}^{K} \beta_{j} X_{t-j},
$$

where $Y_{t}$ is the dependent, or output, variable at time $t, X_{t-j}$ is the independent variable at time $t-j$, and $\beta_{\mathrm{j}}$ are the coefficients of the lag structure, $\beta_{0}, \beta_{1}, \ldots, \beta_{\mathrm{K}}$. Also, $K$ is the number of past periods covered by the lag function; therefore, there are $\mathrm{K}+1$ coefficients to be estimated (Almon 1965; Griliches 1967). A polynomial distributed lag model assumes that the lag weights can be specified by a continuous function. This function can be approximated by evaluating the polynomial at discrete points in time (Pindyck and Rubinfeld 1981).

Preliminary models revealed that the data most closely followed a second order polynomial. The response at first increases at a decreasing rate until it reaches a maximum. Then the response decreases at an increasing rate until it reaches zero and has no further measurable effect. This lag pattern concurs with the findings of similar studies of transportation expenditures and economic activity (Stephanedes 1989; Crane, Burke, and Hanks 1991). Consequently, it is assumed in this paper that the effect of transportation expenditures on the economy follows this rather simple response reaction, and therefore, a second order finite polynomial is used to estimate the function. Equation (1) can then be rewritten as: 


$$
Y_{t}=\sum_{j=0}^{K}\left(\alpha_{0}+\alpha_{l j}+\alpha_{2 j}^{2}\right) X_{t-j},
$$

where

$$
\beta_{j}=\alpha_{0}+\alpha_{l j}+\alpha_{2 j}^{2}=0 \text {. }
$$

This restriction on $\beta_{j}$, that $\beta_{j}=0$ when $j=k$, is imposed because of the assumption that beyond some time period $\mathrm{j}, \mathrm{Y}_{\mathrm{t}}$ is no longer affected by a change in the independent variable $\mathrm{X}$. That is, a second degree polynomial was used because of the assumption that the dependent variables' (income and employment) response over time to changes in transportation expenditures increases at a decreasing rate up to a maximum effect and then decreases over time at an increasing rate until it reaches zero (Ethridge 1975).

The elasticities $\left(\varepsilon_{\mathrm{j}}\right)$ are also calculated for each time period of the distributed lag. The elasticity of output associated with a change in the level of transportation expenditures at any point in time can be calculated as:

$$
\varepsilon_{j}=\frac{\partial Y_{t}}{\partial X_{t-j}} \cdot \frac{\bar{X}}{\bar{Y}}
$$

and the cumulative effect or total elasticity ( $\varepsilon_{\text {TOTAL }}$ ) for all of the $k$ lags is

$$
\varepsilon_{\text {TOTAL }}=\sum_{j=0}^{K} \varepsilon_{j}
$$

where $\bar{X}$ is the mean value of transportation expenditures, and $\bar{Y}$ is the mean of the dependent variable, income, or employment (Chen, Courtney, and Schmitz 1972).

The independent variables in the models were oil prices, gross national product (GNP), transportation expenditures, and lagged values of transportation expenditures using Equation (2). These variables were regressed against two classifications of dependent variables, income and employment, for (1) the farm sector and (2) the nonfarm sector in both urban and rural regions. An analysis was also done on the effects of transportation expenditures on rural income in selected subsectors of the nonfarm sector, namely, the construction, manufacturing, wholesale trade, retail trade, and services sectors. 


\section{Data}

The data consist of annual observations for the 254 counties of Texas, covering a time period from 1969 through 1986. The data for the economic variables are personal income and employment values at the county level by major industry Standard Industrial Classification (S.I.C.) as collected by the U.S Department of Commerce (Regional Economic Information System 1989), expenditures for transportation (maintenance and construction), GNP, and crude oil prices (Texas Railroad Commission 1986). The highway construction and maintenance expenditures are those reported by the Texas State Department of Highways and Public Transportation in their biennial reports. The nominal dollar values were deflated into real dollars using the GNP implicit price deflators $(1982=100)$ reported in the Economic Report of the President (1988).

Oil prices were used as a surrogate variable to measure the general health of the Texas state economy, because the oil industry in Texas is the dominant industry. A major source of state revenue and monies for highway maintenance and construction is from the oil industry and its related businesses. GNP was included to account for general economic trends and conditions. Moreover, one would expect both oil prices and GNP to have a positive relationship with total income and employment. However, in sectors that rely heavily on petroleum-based inputs, a negative relationship with oil price is likely.

The data were separated into four groups to test for the difference between urban and rural counties and between east and west counties. It was originally hypothesized that there would possibly be a difference in how transportation expenditures affected the local economy, resulting from the vast open spaces and longer traveling distances in west Texas. For use in the statistical analysis, the transportation expenditures, the individual county employment data, and the total personal income data are aggregated annually within each of the four different categories. Aggregating within the categories had the effect of capturing the intercounty relationships. This assumption means that when a highway is constructed, the economic benefits of this expenditure are felt in the surrounding geographic area and not only in the counties that it intersects. For the price of crude oil, the mean values (calculated from the counties within each category) are used.

An urban county was one that included one or more metropolitan statistical area (MSA). A MSA is a geographical area containing 50,000 or more inhabitants. Using this definition, there are 49 urban counties and 205 rural counties in Texas. East Texas was defined to include all of the counties east of Interstate Highway 35 (I-35). There are 120 counties in east Texas and 134 in west Texas. There are 38 and 11 urban counties in east and west Texas, respectively, and there are 82 and 123 rural counties in east and west Texas, respectively. 


\section{EMPIRICAL RESULTS}

Using a second order polynomial lag (Equation 2), regression estimates were obtained for combinations of the urban/rural east/west categories. Sorting the analysis by east versus west did not contribute significantly to explaining the effects of transportation expenditures on income and employment levels. In all models comparing east/west differences in effect, the null hypothesis (Ho: $\beta=0$ ) could not be rejected based on the t-statistics from the analysis. Consequently the results reported in this paper are only for urban and rural categories.

\section{Income}

Regression estimates, elasticities, and lag lengths for farm, nonfarm, and total income in urban counties and rural counties are reported in Table 1 and Table 2, respectively. There is a difference in the number of transportation expenditure lags between urban and rural counties. A five-year lag model best fits the urban income data in both the farm and nonfarm sectors. However, for the rural income data, a four-year lag was the most significant in the farm sector, and a sixyear lag was best in the nonfarm sector. The correct length of lag was determined by selecting the lag that resulted in the smallest standard error of regression. All coefficients were statistically significant, except for the coefficient on oil prices when farm income in urban counties was estimated (Table 1). Thus, changes in oil price did not have a significant effect on farm income in urban counties.

The income elasticities with respect to transportation expenditures for each time period, as well as the total cumulative elasticity, are reported in Tables 1 and 2 . The results show that for a change in transportation expenditures at time $t=0$, the income elasticities are 0.208 for the farm sector in urban counties, 0.279 for the farm sector in rural counties, 0.120 for the nonfarm sector in urban counties, and 0.072 for the nonfarm sector in rural counties. These elasticities peak or reach their maximum at time $t+2$ in the rural farm sector and at $t+3$ in the rural nonfarm sector. In both urban sectors, the maximum is between periods 2 and 3 .

Moreover, the total percentage increase in income from a 1 percent change in transportation expenditures is given by the total elasticities, which are 1.944 for the farm sector in urban counties, 1.938 for the farm sector in rural counties, 1.120 for the nonfarm sector in urban counties, and 0.860 for the nonfarm sector in rural counties. The sum of the lagged regression coefficients in the nonfarm sector are considerably larger because the nonfarm sector economy is larger than the farm sector economy. For example, one dollar spent on transportation is associated with 0.543 dollars of farm income in rural counties after four years, and 2.325 dollars of nonfarm income in rural counties after six years. 
TABLE 1

Polynomial Lag Regression Estimates and Elasticities for Income in Urban Counties

\begin{tabular}{|c|c|c|c|c|c|c|}
\hline \multirow[b]{2}{*}{ Variables } & \multicolumn{2}{|c|}{ Total Income } & \multicolumn{2}{|c|}{ Farm Income $e^{c}$} & \multicolumn{2}{|c|}{ Nonfarm Income } \\
\hline & $\begin{array}{l}\text { Coef- } \\
\text { ficient }\end{array}$ & $\begin{array}{l}\text { Elas- } \\
\text { ticity } \\
\end{array}$ & $\begin{array}{l}\text { Coef- } \\
\text { ficient }\end{array}$ & $\begin{array}{l}\text { Elas- } \\
\text { ticity }\end{array}$ & $\begin{array}{l}\text { Coef- } \\
\text { ficient }\end{array}$ & $\begin{array}{l}\text { Elas- } \\
\text { ticity }\end{array}$ \\
\hline Constant & $\begin{array}{c}-296,320,000 \\
(-20.216)\end{array}$ & & $\begin{array}{l}-78,316 \\
(-3.433)\end{array}$ & & $\begin{array}{c}-295,540,000 \\
(-20.153)\end{array}$ & \\
\hline Oil & $\begin{array}{c}44,646,000 \\
(4.584)^{2}\end{array}$ & & $\begin{array}{l}14,001 \\
(0.092)\end{array}$ & & $\begin{array}{r}44,632,000 \\
(4.580)^{4}\end{array}$ & \\
\hline GNP & $\begin{array}{l}86,061 \\
(15.370)^{a}\end{array}$ & & $\begin{array}{l}124.82 \\
(1.432)^{b}\end{array}$ & & $\begin{array}{c}85.936 \\
(15.340)^{\mathrm{a}}\end{array}$ & \\
\hline $\begin{array}{l}\text { Distributed } \\
\text { lags for } \\
\text { transportation } \\
\text { expenditures: }\end{array}$ & & & & & & \\
\hline 0 & $\begin{array}{l}1.500 \\
(5.712)^{a}\end{array}$ & 0.120 & $\begin{array}{l}0.012 \\
(2.963)^{2}\end{array}$ & 0.208 & $\begin{array}{c}1.488 \\
(5.663)^{a}\end{array}$ & 0.120 \\
\hline 1 & $\begin{array}{c}2.501 \\
(5.712)^{2}\end{array}$ & 0.201 & $\begin{array}{l}0.021 \\
(2.963)^{2}\end{array}$ & 0.347 & $\begin{array}{l}2.481 \\
(5.663)^{a}\end{array}$ & 0.200 \\
\hline 2 & $\begin{array}{c}3.001 \\
(5.712)^{a}\end{array}$ & 0.241 & $\begin{array}{c}0.024 \\
(2.963)^{a}\end{array}$ & 0.417 & $\begin{array}{c}2.977 \\
(5.663)^{a}\end{array}$ & 0.240 \\
\hline 3 & $\begin{array}{c}3.001 \\
(5.712)^{a}\end{array}$ & 0.241 & $\begin{array}{l}0.024 \\
(2.963)^{\mathrm{a}}\end{array}$ & 0.417 & $\begin{array}{l}2.977 \\
(5.663)^{a}\end{array}$ & 0.240 \\
\hline 4 & $\begin{array}{c}2.501 \\
(5.712)^{a}\end{array}$ & 0.201 & $\begin{array}{l}0.021 \\
(2.963)^{a}\end{array}$ & 0.347 & $\begin{array}{c}2.481 \\
(5.663)^{a}\end{array}$ & 0.200 \\
\hline 5 & $\begin{array}{l}1.500 \\
(5.712)^{a}\end{array}$ & 0.120 & $\begin{array}{c}0.012 \\
(2.963)^{\mathrm{a}}\end{array}$ & 0.208 & $\begin{array}{c}1.488 \\
(5.663)^{a}\end{array}$ & 0.120 \\
\hline $\begin{array}{l}\text { Sum of lag } \\
\text { coefficients } \\
\text { and elasticities }\end{array}$ & 14.004 & 1.124 & 0.113 & 1.944 & 13.891 & 1.120 \\
\hline Adjusted $\mathbf{R}^{2}$ & 0.986 & & 0.708 & & 0.986 & \\
\hline $\begin{array}{l}\text { Durban- } \\
\text { Watson } \\
\text { statistic }\end{array}$ & 2.433 & & 2.389 & & 2.442 & \\
\hline
\end{tabular}

Numbers in parenthesis are t-statistics.

${ }^{2}$ Statistically different from zero at the 5 percent level of significance.

bstatistically different from zero at the 10 percent level of significance.

c Corrected for serial correlation using the Cochrane-Orcutt procedure.

An increase in oil prices decreased farm income in rural counties (Table 2). The results show that a higher cost of farm production overshadows any other benefits that may come from higher oil prices. Petroleum is a production input in farming, and an increase in oil prices will increase farmers' cost of production. Farmers purchase large amounts of fuel for operation of farm equipment and for 
TABLE 2

Polynomial Lag Regression Estimates and Elasticities for Income in Rural Counties

\begin{tabular}{|c|c|c|c|c|c|c|}
\hline \multirow[b]{2}{*}{ Variables } & \multicolumn{2}{|c|}{ Total Income } & \multicolumn{2}{|c|}{ Farm Income $e^{c}$} & \multicolumn{2}{|c|}{ Nonfarm Income } \\
\hline & $\begin{array}{l}\text { Coef- } \\
\text { ficient }\end{array}$ & $\begin{array}{l}\text { Elas- } \\
\text { ticity }\end{array}$ & $\begin{array}{l}\text { Coef- } \\
\text { ficient } \\
\end{array}$ & $\begin{array}{l}\text { Elas- } \\
\text { ticity }\end{array}$ & $\begin{array}{l}\text { Coef- } \\
\text { ficient }\end{array}$ & $\begin{array}{l}\text { Elas- } \\
\text { ticity }\end{array}$ \\
\hline Constant & $\begin{array}{c}-40,099,000 \\
(-11.512)\end{array}$ & & $\begin{array}{r}-4,111,800 \\
(-7.513)\end{array}$ & & $\begin{array}{c}-36,876,000 \\
(-12.631)\end{array}$ & \\
\hline Oil & $\begin{array}{c}7,040,300 \\
(4.007)^{2}\end{array}$ & & $\begin{array}{r}-1,073,600 \\
(-3.145)^{2}\end{array}$ & & $\begin{array}{r}6,943,800 \\
(4.715)^{a}\end{array}$ & \\
\hline GNP & $\begin{array}{c}12,265 \\
(13.181)^{a}\end{array}$ & & $\begin{array}{l}993.86 \\
(8.586)^{a}\end{array}$ & & $\begin{array}{c}11,417 \\
(14.638)^{a}\end{array}$ & \\
\hline \multicolumn{7}{|l|}{$\begin{array}{l}\text { Distributed } \\
\text { lags for } \\
\text { transportation } \\
\text { expenditures: }\end{array}$} \\
\hline 0 & $\begin{array}{c}0.225 \\
(3.448)^{a}\end{array}$ & 0.075 & $\begin{array}{c}0.078 \\
(5.489)^{2}\end{array}$ & 0.279 & $\begin{array}{c}0.194 \\
(3.543)^{a}\end{array}$ & 0.072 \\
\hline 1 & $\begin{array}{c}0.386 \\
(3.448)^{a}\end{array}$ & 0.129 & $\begin{array}{c}0.124 \\
(5.489)^{2}\end{array}$ & 0.436 & $\begin{array}{c}0.332 \\
(3.543)^{a}\end{array}$ & 0.123 \\
\hline 2 & $\begin{array}{c}0.482 \\
(3.448)^{a}\end{array}$ & 0.161 & $\begin{array}{c}0.139 \\
(5.489)^{a}\end{array}$ & 0.493 & $\begin{array}{c}0.415 \\
(3.543)^{n}\end{array}$ & 0.153 \\
\hline 3 & $\begin{array}{c}0.514 \\
(3.448)^{a}\end{array}$ & 0.172 & $\begin{array}{c}0.124 \\
(5.489)^{a}\end{array}$ & 0.447 & $\begin{array}{c}0.443 \\
(3.543)^{2}\end{array}$ & 0.164 \\
\hline 4 & $\begin{array}{c}0.482 \\
(3.448)^{\mathrm{a}}\end{array}$ & 0.161 & $\begin{array}{c}0.078 \\
(5.489)^{\mathrm{a}}\end{array}$ & 0.283 & $\begin{array}{c}0.415 \\
(3.543)^{a}\end{array}$ & 0.153 \\
\hline 5 & $\begin{array}{c}0.386 \\
(3.448)^{a}\end{array}$ & 0.129 & & & $\begin{array}{c}0.332 \\
(3.543)^{a}\end{array}$ & 0.123 \\
\hline 6 & $\begin{array}{c}0.225 \\
(3.448)^{a}\end{array}$ & 0.075 & & & $\begin{array}{c}0.194 \\
(3.543)^{\mathrm{a}}\end{array}$ & 0.072 \\
\hline $\begin{array}{l}\text { Sum of lag } \\
\text { coefficients } \\
\text { and elasticities }\end{array}$ & 2.699 & 0.902 & 0.543 & 1.938 & 2.325 & 0.860 \\
\hline Adjusted $\mathrm{R}^{2}$ & 0.974 & & 0.822 & & 0.979 & \\
\hline $\begin{array}{l}\text { Durban- } \\
\text { Watson } \\
\text { statistic }\end{array}$ & 2.141 & & $3.205^{d}$ & & 2.242 & \\
\hline
\end{tabular}

Numbers in parenthesis are t-statistics.

${ }^{2}$ Statistically different from zero at the 5 percent level of significance.

bStatistically different from zero at the 10 percent level of significance.

cCorrected for serial correlation using the Cochrane-Orcutt procedure.

${ }^{\mathrm{d}}$ Durban-Watson statistic before correcting for serial correlation. 
the transportation of inputs to the farm and produce to the markets. Also, farmers purchase fertilizers, pesticides, fungicides, and various other chemicals that use petroleum. Feed grains and hay-important inputs in Texas agriculture-are also affected by the cost of fertilizer. The increase in production costs from an increase in oil prices will, of course, lead to a decrease in farm income.

Nonfarm income in rural counties was also separated into five nonfarm subsectors as described above, and each subsector was modeled (Table 3). At the subsector level, oil price was found to be statistically insignificant and was excluded from the model. The coefficients are all statistically significant. As shown by the elasticity sums, the largest percentage increase in nonfarm income in response to an increase in transportation expenditures was in the wholesale trade sector, followed by the retail trade, manufacturing, services, and construction sectors. The greatest overall effect in absolute dollars of income generated was in the retail trade sector. This was followed by the manufacturing, wholesale trade, construction, and service sectors as indicated by the sum of their respective lag regression coefficients.

Serial correlation was present when nonfarm construction income (Table 2) and manufacturing and wholesale income in rural counties (Table 3) were estimated. Serial correlation is a condition where the stochastic disturbance terms are not independent of one another but are serially correlated through time, leading to an incorrect measure of the true error variance. The Durbin-Watson statistic was used to determine when serial correlation was present, and the Cochrane-Orcutt procedure was used to correct for the serial correlation (Pindyck and Rubinfeld 1981, 157).

\section{Employment}

Regression estimates, elasticities, and lag lengths for farm, nonfarm, and total employment in urban counties and rural counties are reported in Table 4 and Table 5, respectively. The length of transportation expenditure lags is uniform between the urban and rural regions. The total effect of transportation expenditures on employment is realized in five years in the farm sector but is realized in nine years in the nonfarm sector. The magnitude of this effect is greater in the urban than in the rural sectors as evidenced by the sum of the lag coefficients.

The sum of the lag coefficients of 0.020 for the rural farm sector (Table 5) means that for a $\$ 1$ million expenditure on transportation maintenance and construction in rural counties in Texas, 20 jobs are created in the farm sector over a five-year period. In the nonfarm rural sector, the sum of the lag coefficient of 0.059 means that a $\$ 1$ million expenditure generates 59 jobs over nine years. Moreover, the sum of the lag coefficients for urban counties (Table 4) shows that 


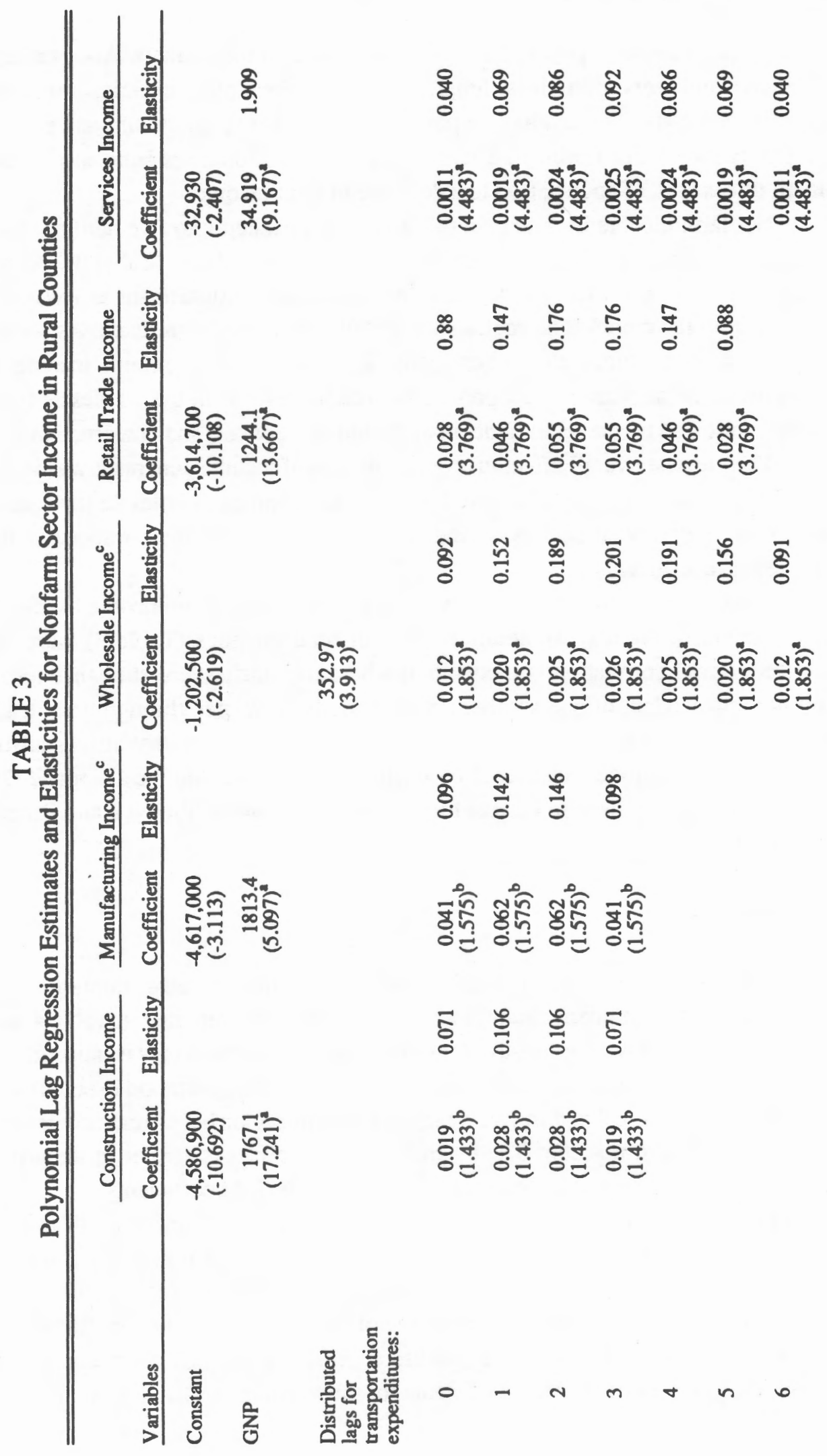




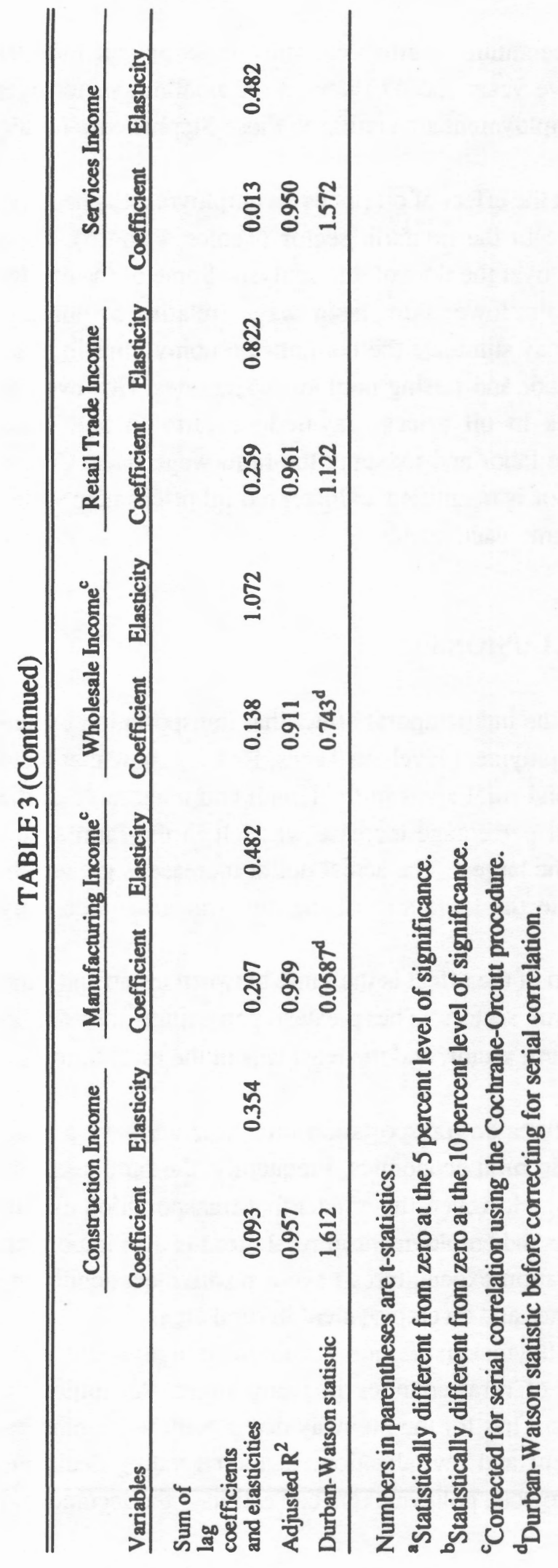


a $\$ 1$ million transportation expenditure in urban counties in Texas generates 91 jobs in the farm sector over five years and 477 jobs in the nonfarm sector over nine years. These results for employment are similar to those Stephanedes (1989) estimated for Minnesota.

It is interesting to note that the effect of oil prices on employment is negative in the farm sector and positive in the nonfarm sector (Tables 4 and 5). Farm employment tended to decrease over the time of this analysis. Some of the exodus of farm labor was a result of the lower farm labor wages relative to nonfarm wages. Increases in oil prices may stimulate the nonfarm economy, thus increasing the demand for nonfarm labor and raising nonfarm wage rates. However, as discussed previously, increases in oil prices may reduce farm income, thus decreasing the demand for farm labor and reducing the farm wage rates. Consequently, the exodus of farm labor is magnified as increased oil prices help widen the gap between farm and nonfarm wage rates.

\section{SUMMARY AND CONCLUSIONS}

In this paper, we evaluate the intertemporal effect that transportation expenditures have on income and employment levels in Texas. Results show that there is a difference between urban and rural areas in the length and magnitude of the impact on income. The greatest percentage increase was felt in the farm sector where the total elasticities are the largest. The actual dollar increase is greatest in the nonfarm urban sector due to the large size of the nonfarm urban economy relative to the rural economy.

For employment, the length of the effect is the same between urban and rural areas for the farm and nonfarm sectors. The greatest percentage increase in employment was in the urban farm sector, and the least was in the rural farm sector.

We conclude that expenditures on transportation infrastructure have a positive and important role to play in rural economies. Frequently, the farm sector is equated as being the rural sector. However, the impact that transportation expenditures have on nonfarm income and employment in rural areas is also important. The results show that transportation expenditures have a positive economic impact on nonfarm and farm incomes and on employment in rural areas.

These results will assist policymakers in their efforts to strengthen and revitalize the declining economies of rural counties in many states. An important aspect of this is the implications it has for the highway department to become involved in economic development and revitalization. In their funding decisions regarding mutually exclusive projects, policymakers can estimate the income and 
TABLE 4

Polynomial Lag Regression Estimates and Elasticities for Employment in Urban Counties

\begin{tabular}{|c|c|c|c|c|c|c|}
\hline \multirow[b]{2}{*}{ Variables } & \multicolumn{2}{|c|}{ Total Income } & \multicolumn{2}{|c|}{ Farm Income } & \multicolumn{2}{|c|}{ Nonfarm Income } \\
\hline & $\begin{array}{l}\text { Coef- } \\
\text { ficient }\end{array}$ & $\begin{array}{l}\text { Elas- } \\
\text { ticity }\end{array}$ & $\begin{array}{l}\text { Coef- } \\
\text { ficient }\end{array}$ & $\begin{array}{l}\text { Elas- } \\
\text { ticity }\end{array}$ & $\begin{array}{l}\text { Coef- } \\
\text { ficient }\end{array}$ & $\begin{array}{l}\text { Elas- } \\
\text { ticity } \\
\end{array}$ \\
\hline Constant & $\begin{array}{c}-2,921,000 \\
(-4.590)\end{array}$ & & $\begin{array}{r}-1,096,700 \\
(-18.230)\end{array}$ & & $\begin{array}{c}-1,503,500 \\
(-2.818)\end{array}$ & \\
\hline Oil & $\begin{array}{r}3,060,200 \\
(5.825)^{a}\end{array}$ & & $\begin{array}{l}-74,745 \\
(-1.872)^{a}\end{array}$ & -0.038 & $\begin{array}{r}1,429,100 \\
(6.488)^{a}\end{array}$ & \\
\hline GNP & $\begin{array}{l}1025.5 \\
(2.198)^{a}\end{array}$ & & $\begin{array}{c}377.97 \\
(16.477)^{a}\end{array}$ & 1.605 & $\begin{array}{l}911.02 \\
(2.328)^{a}\end{array}$ & \\
\hline \multicolumn{7}{|l|}{$\begin{array}{l}\text { Distributed } \\
\text { lags for } \\
\text { transportation } \\
\text { expenditures: }\end{array}$} \\
\hline 0 & $\begin{array}{c}0.033 \\
(3.628)^{a}\end{array}$ & 0.043 & $\begin{array}{c}0.009 \\
(9.054)^{a}\end{array}$ & 0.102 & $\begin{array}{c}0.022 \\
(2.841)^{a}\end{array}$ & 0.032 \\
\hline 1 & $\begin{array}{c}0.060 \\
(3.628)^{a}\end{array}$ & 0.077 & $\begin{array}{c}0.016 \\
(9.054)^{a}\end{array}$ & 0.170 & $\begin{array}{c}0.039 \\
(2.841)^{a}\end{array}$ & 0.058 \\
\hline 2 & $\begin{array}{c}0.079 \\
(3.628)^{a}\end{array}$ & 0.103 & $\begin{array}{c}0.020 \\
(9.054)^{\mathrm{a}}\end{array}$ & 0.204 & $\begin{array}{c}0.520 \\
(2.841)^{a}\end{array}$ & 0.078 \\
\hline 3 & $\begin{array}{c}0.092 \\
(3.628)^{a}\end{array}$ & 0.120 & $\begin{array}{c}0.016 \\
(9.054)^{a}\end{array}$ & 0.204 & $\begin{array}{c}0.606 \\
(2.841)^{a}\end{array}$ & 0.091 \\
\hline 4 & $\begin{array}{c}0.099 \\
(3.628)^{a}\end{array}$ & 0.129 & $\begin{array}{c}0.016 \\
(9.054)^{a}\end{array}$ & 0.170 & $\begin{array}{l}0.650 \\
(2.841)^{a}\end{array}$ & 0.097 \\
\hline 5 & $\begin{array}{c}0.099 \\
(3.628)^{a}\end{array}$ & 0.129 & $\begin{array}{c}0.009 \\
(9.054)^{a}\end{array}$ & 0.102 & $\begin{array}{c}0.650 \\
(2.841)^{a}\end{array}$ & 0.097 \\
\hline 6 & $\begin{array}{c}0.092 \\
(3.628)^{a}\end{array}$ & 0.120 & & & $\begin{array}{c}0.606 \\
(2.841)\end{array}$ & 0.091 \\
\hline 7 & $\begin{array}{c}0.079 \\
(3.628)^{a}\end{array}$ & 0.103 & & & $\begin{array}{c}0.520 \\
(2.841)^{2}\end{array}$ & 0.078 \\
\hline 8 & $\begin{array}{c}0.060 \\
(3.628)^{a}\end{array}$ & 0.077 & & & $\begin{array}{c}0.039 \\
(2.841)^{\mathrm{a}}\end{array}$ & 0.058 \\
\hline 9 & $\begin{array}{c}0.033 \\
(3.628)^{\mathrm{a}}\end{array}$ & 0.043 & & & $\begin{array}{l}0.022 \\
(2.841)^{a}\end{array}$ & 0.032 \\
\hline $\begin{array}{l}\text { Sum of lag } \\
\text { coefficients } \\
\text { and elasticities }\end{array}$ & 0.726 & 0.9440 & 0.091 & 0.952 & 0.477 & 0.712 \\
\hline Adjusted $\mathbf{R}^{2}$ & 0.966 & & 0.988 & & 0.959 & \\
\hline $\begin{array}{l}\text { Durban- } \\
\text { Watson } \\
\text { statistic }\end{array}$ & 3.008 & & 2.803 & & 2.995 & \\
\hline
\end{tabular}

Numbers in parenthesis are t-statistics.

astatistically different from zero at the 5 percent level of significance. 
TABLE 5

Polynomial Lag Regression Estimates and Elasticities for Employment in Rural Counties

\begin{tabular}{|c|c|c|c|c|c|c|}
\hline \multirow[b]{2}{*}{ Variables } & \multicolumn{2}{|c|}{ Total Income } & \multicolumn{2}{|c|}{ Farm Income } & \multicolumn{2}{|c|}{ Nonfarm Income } \\
\hline & $\begin{array}{l}\text { Coef- } \\
\text { ficient }\end{array}$ & $\begin{array}{l}\text { Elas- } \\
\text { ticity }\end{array}$ & $\begin{array}{l}\text { Coef- } \\
\text { ficient }\end{array}$ & $\begin{array}{l}\text { Elas- } \\
\text { ticity }\end{array}$ & $\begin{array}{l}\text { Coef- } \\
\text { ficient }\end{array}$ & $\begin{array}{l}\text { Elas- } \\
\text { ticity }\end{array}$ \\
\hline Constant & $\begin{array}{l}25,128 \\
(2.067)\end{array}$ & & $\begin{array}{r}127,900 \\
(4.062)\end{array}$ & & $\begin{array}{l}201,480 \\
(2.027)\end{array}$ & \\
\hline Oil & $\begin{array}{c}410,270 \\
(5.249)^{\mathrm{a}}\end{array}$ & & $\begin{array}{l}-18,869 \\
(-1.084)\end{array}$ & -0.019 & $\begin{array}{l}193,800 \\
(6.058)^{a}\end{array}$ & \\
\hline GNP & $\begin{array}{l}99.363 \\
(1.826)^{2}\end{array}$ & & $\begin{array}{l}48.623 \\
(6.847)^{a}\end{array}$ & 0.403 & $\begin{array}{c}99.377 \\
(2.234)^{\mathrm{a}}\end{array}$ & \\
\hline \multicolumn{7}{|l|}{$\begin{array}{l}\text { Distributed } \\
\text { lags for } \\
\text { transportation } \\
\text { expenditures: }\end{array}$} \\
\hline 0 & $\begin{array}{l}0.006 \\
(2.702)^{\mathrm{a}}\end{array}$ & 0.024 & $\begin{array}{c}0.002 \\
(3.161)^{\mathrm{a}}\end{array}$ & 0.031 & $\begin{array}{l}0.003 \\
(1.584)^{b}\end{array}$ & 0.017 \\
\hline 1 & $\begin{array}{c}0.011 \\
(2.702)^{\mathrm{a}}\end{array}$ & 0.044 & $\begin{array}{c}0.003 \\
(3.161)^{\mathrm{a}}\end{array}$ & 0.051 & $\begin{array}{c}0.005 \\
(1.584)^{b}\end{array}$ & 0.030 \\
\hline 2 & $\begin{array}{l}0.013 \\
(2.702)^{\mathrm{a}}\end{array}$ & 0.058 & $\begin{array}{c}0.004 \\
(3.161)^{a}\end{array}$ & 0.061 & $\begin{array}{c}0.006 \\
(1.584)^{b}\end{array}$ & 0.040 \\
\hline 3 & $\begin{array}{c}0.015 \\
(2.702)^{\mathrm{a}}\end{array}$ & 0.068 & $\begin{array}{c}0.004 \\
(3.161)^{\mathrm{a}}\end{array}$ & 0.061 & $\begin{array}{l}0.007 \\
(1.584)^{b}\end{array}$ & 0.047 \\
\hline 4 & $\begin{array}{c}0.017 \\
(2.702)^{\mathrm{a}}\end{array}$ & 0.073 & $\begin{array}{c}0.003 \\
(3.161)^{a}\end{array}$ & 0.051 & $\begin{array}{l}0.008 \\
(1.584)^{b}\end{array}$ & 0.050 \\
\hline 5 & $\begin{array}{c}0.017 \\
(2.702)^{\mathrm{a}}\end{array}$ & 0.073 & $\begin{array}{c}0.002 \\
(3.161)^{a}\end{array}$ & 0.031 & $\begin{array}{c}0.008 \\
(1.584)^{b}\end{array}$ & 0.050 \\
\hline 6 & $\begin{array}{c}0.015 \\
(2.702)^{\mathrm{a}}\end{array}$ & 0.068 & & & $\begin{array}{l}0.007 \\
(1.584)^{b}\end{array}$ & 0.047 \\
\hline 7 & $\begin{array}{c}0.013 \\
(2.702)^{\mathrm{a}}\end{array}$ & 0.058 & & & $\begin{array}{c}0.006 \\
(1.584)^{b}\end{array}$ & 0.040 \\
\hline 8 & $\begin{array}{c}0.011 \\
(2.702)^{a}\end{array}$ & 0.044 & & & $\begin{array}{l}0.005 \\
(1.584)^{b}\end{array}$ & 0.030 \\
\hline 9 & $\begin{array}{l}0.006 \\
(2.702)^{\mathrm{a}}\end{array}$ & 0.024 & & & $\begin{array}{l}0.003 \\
(1.584)^{b}\end{array}$ & 0.017 \\
\hline $\begin{array}{l}\text { Sum of lag } \\
\text { coefficients } \\
\text { and elasticities }\end{array}$ & 0.123 & 0.534 & 0.020 & 0.286 & 0.059 & 0.368 \\
\hline Adjusted $\mathbf{R}^{2}$ & 0.919 & & 0.878 & & 0.905 & \\
\hline $\begin{array}{l}\text { Durban- } \\
\text { Watson } \\
\text { statistic }\end{array}$ & 2.849 & & 1.226 & & 3.028 & \\
\hline
\end{tabular}

Numbers in parenthesis are t-statistics.

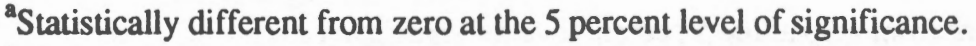

btatistically different from zero at the 10 percent level of significance. 
employment impacts and consider them for inclusion in their project ranking, rating, and assessment techniques. The differential effects across sectors and industries can be estimated and included in their strategic planning and policy formation regarding statewide economic diversification.

\section{REFERENCES}

Almon, Shirley. "The Distributed Lag Between Capital Appropriations and Expenditures." Econometrica 33, no. 1 (1965): 178-186.

Altshuler, Alan A. "Changing Patterns of Policy: The Decision Making Environment of Urban Transportation." Public Policy 25 (1977): 171-203.

Anderson, James E., Richard W. Murray, and Edward L. Farley. Texas Politics. New York: Harper \& Row, 1984.

Briggs, Ronald. "The Impact of the Interstate Highway System on Nonmetropolitan Development, 1950-80." In Beyond the Urban Fringe, edited by Rutherford H. Platt and George Machinko, 83-105. Minneapolis: University of Minnesota Press, 1983.

Carlino, Gerald A., and Edwin S. Mills. "The Determinants of County Growth." Journal of Regional Science 27, no. 1 (1987): 39.

Carlton, D. "The Location and Employment Choices of New Firms: An Econometric Model with Discrete and Continuous Endogenous Variables." The Review of Economics and Statistics 65 (1983): 440-49.

Center for Applied Research. "Funding Transportation Needs in the North Central Texas Area." University of Texas, Dallas, January 18, 1987.

Chen, Dean, Richard Courtney, and Andrew Schmitz. "A Polynomial Lag Formulation of Milk Production Response." American Journal of Agricultural Economics 54, no. 1 (1972): 78-83.

Cherwony, Walter, and Phillip A. Cartwright. "Casino Bus Transportation System." Transportation Research Record 984 (1985): 51-56.

Crane, Laurence M., Dock Burke, and Clay Hanks. "Highway District and Economic Sector Employment Effects of Transportation Expenditures." Transportation Research Record 1305 (1991):190-200.

Dye, Thomas R. Politics, Economics, and the Public: Policy Outcomes in the American States. Chicago: Rand McNally \& Co., 1966.

. "Taxing, Spending, and Economic Growth in The American States." The Journal of Politics 42 (1980): 1085-1107.

Eagle, David, and Yorgos J. Stephanedes. "Dynamic Highway Impacts on Economic Development." Transportation Research Record 1116 (1987): 5662. 
Ethridge, M. Dean. "Estimating the Structure of Time Lags Between Wholesale and Farm Prices for Cottonseed." Southern Journal of Agricultural Economics (1975): 169-175.

Forkenbrock, David J., and David J. Plazak. "Economic Development and StateLevel Transportation Policy." Transportation Quarterly 40 (1986): 143-157.

Griliches, Zvi. "Distributed Lags: A Survey." Econometrica 35, no. 1 (1967): 1649.

Herzog, Henry W., Alan M. Schlottmann, and Donald L. Johnson. "High-Technology Jobs and Worker Mobility." Journal of Regional Science 26 (1986): 445-460.

Hoselitz, Bert F., Joseph J. Spengler, J. M. Letiche, Erskine McKinley, John Buttrick, and Henry J. Bruton. Theories of Economic Growth. Glencoe, Ill.: The Free Press, 1960.

Jhingan, M. L. The Economics of Development and Planning. New York: Vikas Publishing House PVT LTD., 1975.

John, DeWitt, Sandra S. Batie, and Kim Norris. "A Brighter Future for Rural America?: Strategies for Communities and States." National Governors' Association, Washington, D.C.: Center for Policy Research, 1988, p. 120.

Knutson, Ronald D., and Dennis U. Fisher. "Options in Developing a New National Rural Policy." Proceedings of four regional Rural Development Policy Workshops, Texas Agricultural Extension Service, Texas A\&M University System, 1989.

Pindyck, Robert S., and Daniel L. Rubinfeld Econometric Models and Economic Forecasts. 2d ed. St. Louis: McGraw-Hill Book Company, 1981.

Politano, Arturo L., and Carol J. Roadifer. "Regional Economic Impact Model for Highway Systems (REIMHS)." Transportation Research Record 1229. Washington, D.C.: TRB, National Research Council, 1989, pp. 43-52.

Roggenburk, Ronald J., and Rasin K. Mufti. "Transportation Planning for Enterprise Development Areas." Transportation Research Record 1046 (1985): 15-17.

Siccardi, A. J. "Economic Effects of Transit and Highway Construction and Rehabilitation." Journal of Transportation Engineering 20, no.1 (1986): 6375.

Stephanedes, Yorgos J. "Transportation and Economic Development: The Link Between Highway Investment and Economic Development-a Time-Series Investigation." Minnesota: Department of Transportation, Report No. MN/RC, 1989, p.15.

Stephanedes, Yorgos J., and David M. Eagle. "Highway Expenditures and NonMetropolitan Employment." Journal of Advanced Transportation 20, no. 1 (1986): 43-61. 
. "Highway Impacts on Regional Employment." Journal of Advanced Transportation 21 (1987): 369-389.

Sullivan, Edward C. "Transportation and Economic Development on the Pacific Coast." Institute of Transportation Studies (ITS) Review 12, no. 1 (1988): 4.

Texas Railroad Commission. "Texas Railroad Commission Annual Report." Austin: Oil and Gas Division, 1986.

TRIP. The National Economic Impact of No Federal Highway Funding. Washington, D.C.: The Road Information Program, 1987.

U.S. Congress. "Barriers to Urban Economic Development." Washington, D.C.: Congressional Budget Office, 1978.

U.S. Department of Commerce. Regional Economic Information System. Washington, D.C.: Bureau of Economic Analysis, 1989

U.S. Government. Economic Report of the President. Washington, D.C.: U.S. Government Printing Office, 1988.

Weiner, Edward, and W. Campbell Graeub. "The Current Need for Research in Transportation Management, Administration, and Planning." TR News 127 (1986): 11-14.

Wilson, F. R., Albert M. Stevens, and Timothy R. Holyoke. "Impact of Transportation on Regional Development." Transportation Research Record 851 (1982): 13-16.

"Impact of Transportation on Regional Development." Transportation Research Record 831. Washington, D.C.: Transportation Research Board, 1982, pp. 13-16.

Wilson, F. R., G. M. Graham, and Mohamed Aboul-Ela. "Highway Investment As a Regional Development Policy Tool." Transportation Research Record 1046 (1985): 10-14. 